\title{
The Expression Pattern of the Tight Junction Protein Occludin in the Epidermal Context When Comparing Various Physical Samples
}

\author{
Ji Sook Kim and Hyung Seok Jang \\ Department of Pathology, Hanyang University Medical Center, Seoul 04763, Korea
}

\section{신체 부위별 표피에서 밀착연접 단백질 중 오클루딘의 발현도 연구}

\author{
김지숙, 장형석 \\ 한양대학교 서울병원 병리과
}

\begin{abstract}
'Tight junctions (TJ)' have recently been identified in the granular cell layer of the human epidermis, where they contribute to the normal adhesion between keratinocytes and to the physiologic barrier function of the epidermis. Among the TJ proteins in the epidermis, occludin is an important transmembrane protein, which is considered as a major component. The purpose of this study is to investigate whether regional variation exists in the expression of the tight junction protein occludin in normal human epidermis. Indirect immunofluorescence staining for occludin was performed with specimens taken from different areas of normal skin ( 4 from each of 7 different anatomical sites, including the scalp, face, posterior neck, upper arm, abdomen, lower back, and inner thigh). The degrees of the expression-intensity in each specimen were estimated with the reciprocals of positive end-point titer of occludin in an indirect immunofluorescence study. The highest degree expression-intensity of the TJ protein occludin among the different areas of normal epidermis was observed on the face and abdomen with a titer of 600 ( $p=0.001)$. The lowest intensity of expression of occludin was seen in the epidermis from the upper arm. Skin specimens from the scalp, neck, back, and leg demonstrated intermediate degrees of the expression in intensity. The expression of occludin in the skin samples obtained from different locations of the body showed a statistically significant variation. This suggests that there is a certain degree of regional variation in the expression-intensity of TJ protein 'occludin' in the human epidermis.
\end{abstract}

Keywords: Epidermis, Immunofluorescence, Occludin, Skin, Tight junction

This is an Open Access article distributed under the terms of the Creative Commons Attribution Non-Commercial License (http://creativecommons.org/licenses/by-nc/4.0) which permits unrestricted non-commercial use, distribution, and reproduction in any medium, provided the original work is properly cited.

Copyright $\odot 2015$ The Korean Society for Clinical Laboratory Science. All rights reserved.
Corresponding author: Ji Sook Kim Department of Pathology, Hanyang University Medical Center, Seoul 04763, Korea Tel: 82-2-2290-8898

E-mail: zojic93@hanmail.net

Received: September 3, 2015 Revised $1^{\text {st: }}$ October 1, 2015 Revised $2^{\text {nd }}$ : October 7, 2015

Revised $3^{\text {rd }}$ : October 12, 2015 Accepted: October 14, 2015

\section{서 론}

사람의 피부에서 표피는 세포간이음(intercellular junction, $\mathrm{ICJ})$ 구조로 결합된 각질 형성 세포로 구성되며, 외부 환경으로부터 내부기관을 보호하고 인체의 항상성을 유지함에 유익한 역할을 한다.
이러한 표피 ICJ의 역할은 인접한 세포에 액틴 미세필라멘트를 연결시키는 부착이음(adherens junction), 세포골격의 중간 필라 멘트에 연결되어 있는 결합체(desmosome), 화학신호나 전기신호 를 세포에서 다음 세포로 빠르게 이동 할 수 있게 해주는 틈새이음 (gap junction), 그리고 밀착연접(tight junction) 등으로 부르는 
접합구조들로 수행되며 이들 각각에 대한 생물학적 기능에 관해서 도 알려지고 있다(Gumbiner 등, 1996; Green 등, 2000; McGrath 등, 2004).

이들 ICJ 중 밀착연접은 표피 과립세포층의 세포간격(intercellular space)에 존재하며, 세포 사이의 물질 이동을 제한한다. 위 의 ICJ 구조들 중 가장 외측, 즉 표피의 최상부에 위치한다(Gonzalez-Mariscal 등, 2003; Morita 등, 2003; Schneeberger 등, 2004).

이러한 밀착연접 구조물에는 occludin (OC), claudin (CL), juntional adhesion molecule (JAM) 등의 밀착연접 연관단백 (tight junction-associated proteins)이 있다(Balda 등, 2000; Lapierre 등, 2000).

이들은 세포질에 존재하는 판단백(plaque protein)인 zona occludens-1 (ZO-1)과 cingulin 들을 매개체로 하여 액틴-세포뼈 대(actin cytoskeleton) 및 다수의 세포질조절단백(cytosolic regulatory protein)과 결합하며, 세포간의 부착(adhesion)과 세포 주위 공간을 통한 수분과 물질의 이동을 조절하는 생물학적 장벽기 능(barrier function)을 가진다(Balda 등, 2000; Lapierre 등, 2000; Morita 등, 2003; Schneeberger 등, 2004). 또한, 유전자 전 사와 종양 전이의 억제, 세포증식의 조절, 그리고 세포극성의 유지 에도 부분적으로 관여하는 것으로 알려지고 있다(Gonzalez-Mariscal 등, 2003; Morita 등, 2003).

밀착연접 중 occludin은 가장 일찍 발견된 밀착연접의 대표적 단백성분으로 세포막을 4회 관통하는 내재성 막 단백질로 그 발현 정도가 밀착연접의 생물학적 기능성과 높은 상관관계가 있는 것으 로도 알려져 있다(Schlüter 등, 2004; Matter 등, 2005).

최근 사람 표피에서 occludin의 단순한 발현유무에 관한 연구보 고가 있지만(Pummi 등, 2001; Yoshida 등, 2001; Brandner 등, 2002; Brandner 등, 2003; Malminen 등, 2003), 이들은 주로 피 부질환에서 병변부에서의 occludin 발현유무에 관한 연구들이었 으며 신체 부위별 발현도에 대한 연구는 보고된 바가 없다.

본 연구에서는 occludin에 대한 항체를 이용한 면역형광검사를 시행하여 신체 여러 부위의 정상피부에서 occludin의 발현도를 검 색하고 그 결과를 비교 검토하였다.

\section{재료 및 방법}

\section{1. 실험재료}

본 연구에서 사용된 재료는 환자들의 치료를 위해 임상의사로부 터 절제술이 시행되었으며 모든 병리학적 진단이 완료된 후 폐기되 는 조직들 중에서 수집하였다. 20 세에서 50 세 사이의 건강인 26 명
(남자 13명, 여자 13명)으로부터 채취한 신체 7부위(두피, 얼굴, 목, 팔, 배, 등, 다리)의 피부조직이며, 동일인에서 채취부위가 중복된 경우는 없었다. 이들 재료는 외상이나 일광 등에 의한 손상의 의심 이 없는 피부로서 위의 각 부위별 4 개씩 채취하여 도합 28개의 피부 절편을 실험조직으로 취득하였다. 각 채취 부위는 해부학적 동일성 을 도모하기 위하여 두피는 뒤통수(occiput)의 모발 경계선에서 약 $3 \mathrm{~cm}$ 위쪽, 얼굴은 뺨(cheek)의 가운데 부위, 목은 목덜미(nape) 가운데 부위, 팔은 위팔(upper arm)의 안쪽 가운데 부위, 배는 배꼽 (umbilicus)을 중심으로 반경 $5 \mathrm{~cm}$ 이내에서, 등은 허리뼈(lumbar vertebra) 1 번에서 5 번 사이의 가운데 부위, 다리는 넓적다리 (thigh) 안쪽 가운데 부위로 정하였다. 형광항체실험에서 양성 대 조 조직은 occludin 단백의 존재가 이미 알려진 건강한 생쥐 (mouse)의 상피조직을 사용하였다. 이들 신체 부위별 피부조직 또 는 상피조직은 모두 채취 후 즉시 OCT compound (Sakura Finetechnical Co., Tokyo, Japan)에 포매(embbed)하여 사용 전 까지 $-70^{\circ} \mathrm{C}$ 에서 냉동보관 하였다.

\section{2. 실험방법}

위의 부위별 신체 피부 또는 생쥐의 상피조직은 occludin 항체 를 이용한 간접 면역형광검사에서 기질로서 사용되었으며, 본 형광 염색실험은 냉동 보관된 검체조직은 냉동 절편기(cryostat, Leica) 를 이용하여 $4 \mu \mathrm{m}$ 의 두께로 얇게 잘랐고, poly-L-lysine (Sigma Chemical Co., St. Louis, MO, U.S.A.)으로 처리한 유리 슬라이드 에 부착시킨 후 실온에서 1 시간 동안 건조시켰다.

이후 $100 \%$ acetone에 10 분간 고정하고 10 분간 건조시킨 후, phosphate-buffered saline (PBS, pH 7.4)으로 5분씩 3회 세척하 였다. 그 후, 실험 과정에서 비 특이적 반응을 가급적 제거하기 위하 여 $10 \%$ 농도의 정상 돼지혈청으로 10 분간 반응시켰다.

세포 간 결합에 관여하는 occludin의 부위별 발현도를 알기 위 한 일차항체는 사람 표피 occludin의 carboxy-terminus의 항원결정 인자(epitope)에 반응하는 항 occludin 항체(Rabbit anti-occludin antibody, Zymed, San Francisco, CA, U.S.A.)를 이용하였다.

항 occludin 항체는 $1: 100,200,400,800,1600$ 으로 희석하여 조직 슬라이드 위에 점적하였고, $4^{\circ} \mathrm{C}$ 냉장고에서 20 시간 동안 반응 시킨 후 $\mathrm{PBS}$ 로 5 분씩 3회 세척하였다.

기질에 침착된 일차항체의 반응 침착물 검색을 위하여 바이오틴 이 결합된 돼지에서 얻은 항토끼 IgG (Biotinylated swine anti-rabbit immunoglobulin, Dako Cytomation, Glostrup, Denmark)를 1:100으로 희석하여 실온에서 30분간 반응시켰다.

이들 조직은 $\mathrm{PBS}$ 로 세척한 후 형광 발색물질인 fluorescein isothiocyanate (FITC)가 결합된 streptavidin (Vector Labora- 
tories, Burlingame, CA, U.S.A.)을 1:30으로 희석한 시약으로 1시 간 반응시키고 $\mathrm{PBS}$ 로 세척하였다.

이상의 과정을 거친 조직 슬라이드는 crystal mount (Biomeda Co., Foster city, CA, U.S.A.)로 봉입하여 조직표본을 제작하였다. 위와 같은 방법으로 준비된 28 개의 조직표본들을 2 명의 판독자가 면역형광 현미경(BX51, Olympus, Tokyo, Japan)을 이용하여 200 배의 배율하에서 조직을 관찰하였고, 표피 과립세포층의 세포 간격에서 선상으로 염색반응이 확인되는 경우를 양성으로 판정하 였다.

조직에 발현된 occludin의 발현도는 양성 염색반응을 보이는 일 차항체의 최종 희석배수의 역수(reciprocal of end-point titer)를 구하고 이를 평균한 수로써 항원의 발현도로 산정하였다.

상기 형광염색실험은 동일조직으로 2 회 반복 시행하여 판독 결 과의 재현성 유무도 검토하였다.

동시에 시행한 양성 실험 대조검사는 생쥐의 작은창자 상피조직 을 기질로 하였으며, 음성 실험 대조검사는 일차항체를 사용하지 않고 위의 형광염색실험을 시행하였다.

검체인 피부조직의 생물학적 신선도를 확인하기 위한 대조검사 로는 자가항체의 역가가 1:160인 보통천포창(pemphigus vulgaris) 환자의 혈청을 $1: 40$ 으로 희석하여 동일한 형광염색실험을 시행하 였고, 표피의 세포간격에서 $\mathrm{IgG}$ 침착양성이 확인되는지 관찰하였다.

Table 1. Degrees of expression-intensity of occludin in normal skin specimens from each different region

\begin{tabular}{lc}
\hline \multicolumn{1}{c}{ Region } & Degrees of expression-intensity* \\
\hline Scalp & 300 \\
Face & 600 \\
Posterior neck & 300 \\
Upper arm & 200 \\
Abdomen & 600 \\
Lower back & 400 \\
Inner thigh & 400 \\
\hline
\end{tabular}

${ }^{*} \mathrm{~A}$ reciprocal of the highest dilution ratio-factor of positive staining reactivity.

\section{결 과}

피부조직에서의 occludin의 면역형광반응은 표피 과립세포층 의 세포간격에서 발견할 수 있었고, 피부조직에서의 항원 발현도는 양성반응을 보이는 최종 희석배수의 역수로 표기하였으며, 부위별 각 4개의 조직에서 얻은 수치들을 평균하였다(Table 1, Fig. 1).

각 검체기질에서의 양성반응을 보인 최종 희석배수는 두피에서 는 4 개의 조직 중 2 개에서 $1: 400$, 나머지 2 개의 조직에서는 $1: 200$ 으로 관찰되어, 항원의 발현도는 300 이었으며, 얼굴에서는 4 개의 검체조직 중 2 개에서 1:800, 나머지 2개의 조직에서는 1:400으로 관찰되어, 항원의 발현도는 600으로 산정하였다(Fig. 2A).

목에서 얻은 조직의 최종양성 희석배수는 각 4 개의 조직 중 2 개 의 조직에서 1:400, 나머지 2개의 조직에서는 1:200으로 관찰되 어, 항원의 발현도는 300 이었다.

팔에서 얻은 4 개의 조직은 모두 1:200의 희석배수까지 양성반 응을 보여 항원의 발현도는 200 이었고, 배에서 얻은 조직의 경우 최종 양성 희석배수는 4 개의 조직 중 2 개의 조직에서 1:600, 나머 지 2 개의 조직에서는 $1: 400$ 으로 관찰되어, 항원의 발현도는 600 이 었다(Fig. 2B).

등과 다리에서는 각 4 개의 조직 중 모든 조직에서 1:400의 희석 배수까지 양성반응을 보여 항원의 발현도는 400 으로 표기하였다.

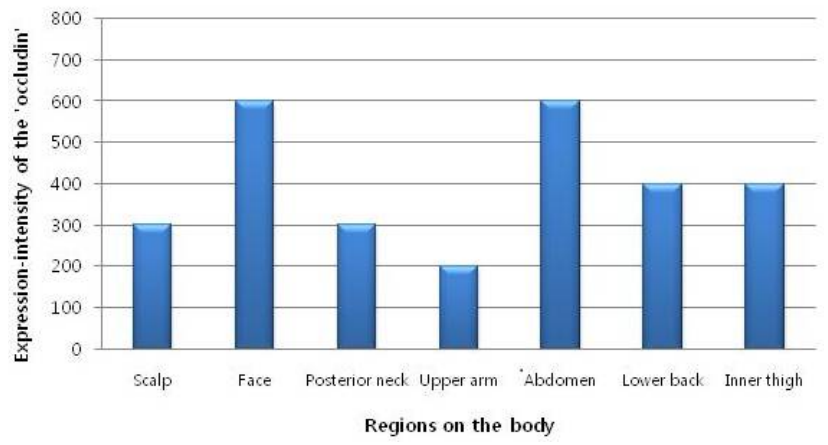

Fig. 1. The expression-intensity of occludin at different regions examined by the indirect immunofluorescence assay.
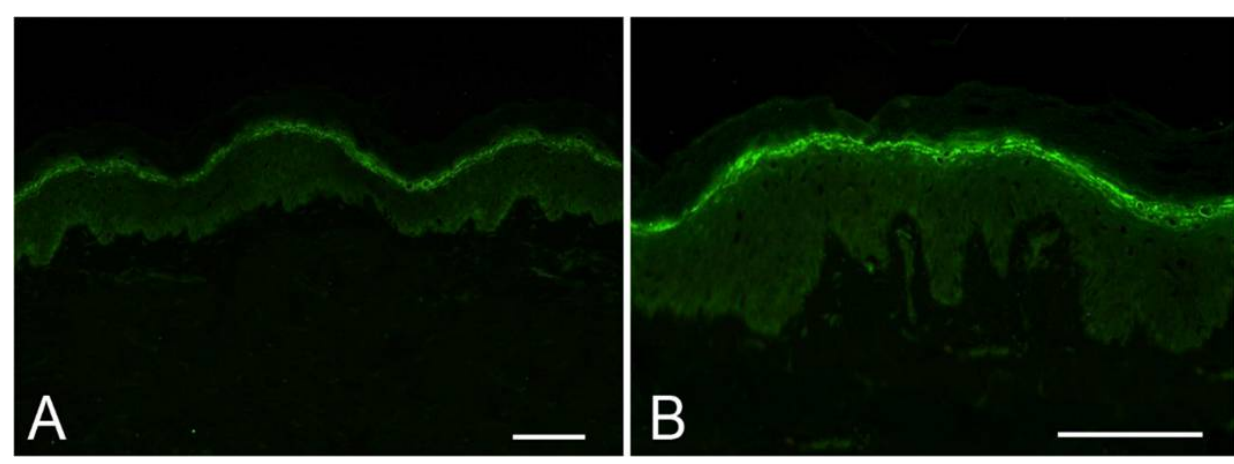

Fig. 2. Indirect immunofluorescence photomicrograph of the occludin expression in normal human skin. The immunofluorescence staining-pattern of occludin observed is a linear staining at the intercellular space of the granular cell layer in the skin, obtained from the face $(A)$, and from the abdomen (B). Scale bars $=100 \mu \mathrm{m}$. 


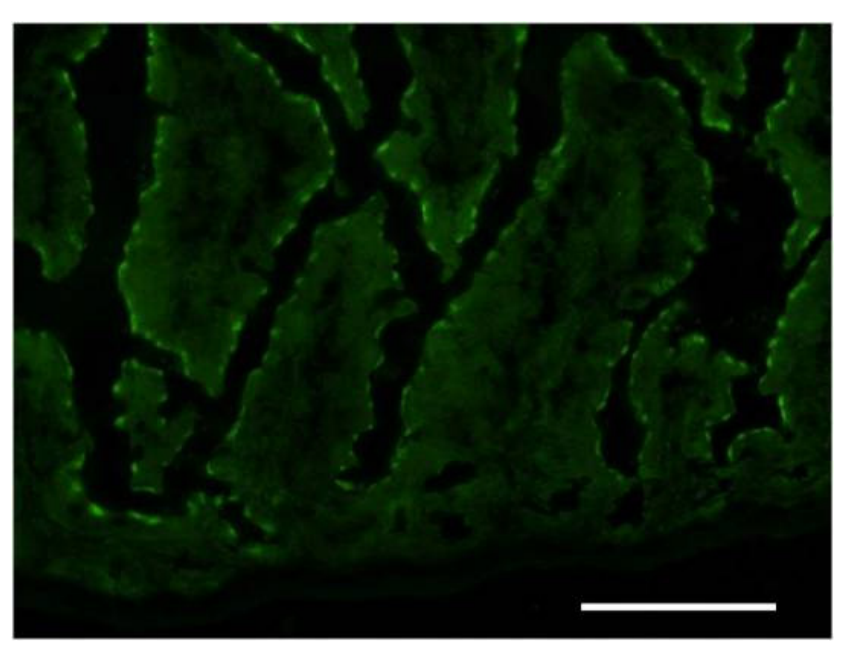

Fig. 3. The immunofluorescence staining of occludin revealed an apicalintercellular staining in the epithelium, obtained from the mouse intestine. Scale bar $=100 \mu \mathrm{m}$.

한편, 동일한 조직으로 반복 시행한 간접 면역형광검사성적은 모든 경우에서 동일한 발현도로 관찰되어 높은 재현성을 보였다.

또한, 항 occludin 항체의 양성 대조 조직으로 사용한 생쥐의 작 은창자 상피조직에서는 세포간격의 꼭대기 부위(apical region)에 서 occludin의 염색반응 양성의 소견을 보였다(Fig. 3).

뿐만 아니라, 보통 천포창 환자의 혈청을 이용한 간접 면역형광 검사에서는 매 실험에 사용한 조직에서 모두 표피의 세포간격에서 $\mathrm{IgG}$ 항체 양성의 염색소견을 보여 표피 단백성분의 신선도를 확인 할 수도 있었다.

판독 결과에 대한 통계학적 고찰로서, 셋 이상의 여러 대상에 대 한 시험에서 서로 다른 결과를 보일 경우 그 의미를 검토하는 데 사 용되는 Kruskal-Wallis test로 위의 신체부위별 발현도를 검정한 결과, 부위별 항 occludin 항체의 희석배수로 산정한 occludin 발 현도는 신체 각 부위별로 차이가 있음이 통계학적으로 유의하였다 ( $p=0.001)$.

\section{고 찰}

인체 피부에서의 이른바 피부장벽(skin barrier)은 표피의 생물 학적 기능을 표현하는 것으로서, 수분과 전해질의 소실을 막고 외 부의 물리적 손상과 화학물질 및 미생물의 침투 등으로부터 인체를 보호하며, 외용 약물의 흡수를 조절하는 등 신체의 중요한 보호벽 으로서의 역할을 가진다(Furuse 등, 2002; Segre 등, 2006).

본 피부장벽과 관련하여 표피의 ICJ에 관한 연구 중 최근 Furuse 등은 밀착연접를 손상시킨 실험 생쥐들에서, 각질층이 존재함에도 불구하고, 경표피수분손실(transepidermal water loss, TEWL)이
매우 증가하는 것을 관찰하였고, 수일 내에 탈수로 사망함을 발견 하였다. 이러한 실험적 사실을 배경으로 하여 피부장벽의 구성요소 중 하나인 밀착연접의 역할이 주목되어 왔다(Hirase 등, 1993).

이 밀착연접을 구성하는 단백물질 중 하나인 occludin은 Hirase 등(1993)에 의해 그 생물학적 기능이 밝혀진 밀착연접의 주요 단백 으로서, 밀착연접에 국한하여 존재하는 밀착연접 특이 단백이다.

Occludin은 밀착연접의 표피 세포 간 부착과 장벽으로서의 기 능에 중요한 역할을 하며, occludin의 발현정도는 밀착연접의 수 또는 양 및 밀착연접 구조의 생물학적 장벽기능성의 고저와도 상관 관계를 보인다(Saitou 등, 1997; Harhaj 등, 2004 ; Feldman 등, 2005).

이번 연구에서는 occludin의 신체 부위별 피부에서 발현정도에 차이가 있는지를 알아보고자 검사를 시행하였으며, occludin는 신 체 모든 부위에서 공통적으로 표피의 과립세포층에 국한되어 세포 간격에서 발현되었다.

한편, occludin의 발현정도에서는 부위에 따른 차이를 보였으 며, 얼굴과 배에서 그 발현도가 600 으로 가장 높았으며, 등과 다리 에서는 400 , 두피와 목에서는 300 , 팔에서는 200 으로서 검사한 부 위들 중 가장 낮았다.

이와 같이 신체 부위에 따라 occludin의 발현의 차이가 관찰된 배경으로는 occludin 단백 자체의 태생적 특성으로 인한 부위별 차 이, 표피의 각질형성세포에 가해지는 비틀림힘(shear strength)의 부위별 차이에 의한 occludin의 발현도의 차등 가능성(Conklin 등, 2002), 부위별 표피 과립세포층에서의 세포의 수적 밀도의 차 이에 의하여 occludin의 발현도에 차등을 보일 가능성(Huzaira 등, 2001), 혹은 부위별 물리화학적인 손상이나 감염 등에 의한 각 질층의 지속적인 손상에 대하여 피부장벽을 유지하기 위한 보상기 전에 의한 occludin의 발현증가 등을 생각해 볼 수 있다.

그러나 본 연구에서 부위별 발현의 차이가 나타난 배경에 대해 서는 연관사실을 논하기가 쉽지 않다. 이러한 occludin의 부위별 차이는 곧 밀착연접의 표피에서의 장벽기능의 부위별 차이와 상관 관계를 보인다고 할 수 있다(Saitou 등, 1997; Harhaj 등, 2004; Feldman 등, 2005).

콩팥에서 근위세관(proximal tubule)과 원위세관(distal tubule) 의상피세포에서 부위별로 occludin 분포의 양적 차이를 검색해 본 결과 밀착연접의 장벽기능을 대변하는 경표피저항(transe-pithelial resistance)의 저항차이의 정도와 의미있는 연관성을 보였다 (Gonzalez-Mariscal 등, 2000).

또한, 신경조직의 혈관내피세포에서는 occludin의 발현도가 높 아 매우 치밀한 장벽을 형성한다고도 하지만, 심장이나 골격근 등 에서의 조직 혈관은 occludin의 발현도가 상대적으로 낮아 비교적 
혈관내피의 투과도가 높아진다고 사료된다(Hirase 등, 1997). 이 렇듯 혈관에서도 부위별로 occludin의 발현도는 밀착연접의 장벽 기능과 병행하는 소견을 가지며 기능적 차이를 나타낸다고 보고되 어 있다.

생물학적으로 occludin는 표피에서 각질형성세포 사이의 세포 주위 공간을 통한 수분의 소실을 막고 전해질의 이동을 조절하여 체내에 수분과 전해질의 균형을 유지하며(Van Itallie 등, 1997), 집 먼지 진드기와 같은 알레르기항원이나 황색포도알균을 비롯한 다 양한 미생물이 표피를 침투하는 것을 방어하는 방어벽으로도 작용 한다(Wan 등, 1999; Ohnemus 등, 2007). 그 밖에도 세포의 극성 을 유지하며, 다양한 세포내 신호전달과정에 참여하여 세포의 증식 과 분화를 조절하고, 종양과 관련한 성장인자의 이동을 방해함으로 써 종양의 전이를 억제하는 역할을 수행한다(Harhaj 등, 2004; Feldman 등, 2005).

현재까지 사람의 표피에서 occludin 발현도의 부위별 차이에 따 른 표피장벽의 기능적 성격의 차등소견에 대한 연구보고는 없으나, 밀착연접 관련의 기존의 연구 결과로 미루어볼 때, 사람의 표피에 서도 occludin의 발현도의 부위별 차이는 밀착연접의 양적 차이를 반영할 수도 있고, 이는 피부장벽의 주요 구성요소인 밀착연접의 장벽기능이 신체부위별로 차등소견을 나타냄을 의미할 수 있다고 생각한다. 밀착연접은 표피 과립세포층에 위치하므로, 각질층을 제거한 후의 TEWL은 밀착연접의 장벽기능 관련 생물학과 연관되 어 생각할 수도 있다.

Fluhr 등(2002)의 연구에서는 사람의 부위별 표피에서 테이프 박리법(tape-stripping method)으로 각질층을 벗겨낸 후에 TEWL 율을 측정한 결과, TEWL이 해부학적 부위로 보아 이마(forehead) 가 TEWL이 가장 높고, 등(upper back), 아래팔(forearm), 배 (abdomen)와 종아리(lower leg) 순으로 낮았다. 이러한 부위별 차 이는 밀착연접의 수량 및 기능적 측면에서의 차등가능성을 간접적 으로 시사하는 바가 있다.

이는 occludin의 발현도가 배와 다리에서 비교적 높고, 팔에서 낮게 나타난 부위별 차이를 보인 본 연구의 결과와는 유사한 점이 발견되지 않으나, 측정부위가 상호 상이할 뿐 아니라, 테이프 박리 법은 측정부위에서 각질층의 두께 및 지질함유량, 측정부위의 하부 에 돌출된 뼈의 유무 등 여러 가지 요인에 의하여 영향을 받을 수 있 기 때문에 본 연구에서와 상호 비교 가능한 의미를 설명하기는 어 려울 것으로 생각한다.

한편, 본 연구와 같은 경우 대상조직의 선택에 있어서 한 개인에 서 신체 부위별로 여러 조직을 채취하여 검사하고 이를 여러 명을 대상으로 시행함이 이상적이겠으나, 동일인에서 다수의 정상 피부 조직을 채취하기에는 동의를 얻기가 쉽지 않은 현실적 문제로 인하
여 채취에 어려움이 있었고, 그로 인하여 대상 조직의 선정과 부위 별 결과의 비교 고찰에는 다소간 부적합한 면도 있으리라 본다.

결론적으로, 본 연구결과 밀착연접의 주요단백인 occludin이 신체 부위별로 발현도의 차이를 보인 것은, 위에서 언급한 대상조 직 채집의 문제도 있겠으나, 여러 학자들의 연구 성과와 함께 고려 할 때 밀착연접의 생물학적 기능이 큰 비중을 차지하는 표피의 장 벽기능의 가능한 부위별 차등성과도 관계가 있을 것으로 짐작되며, 향후 occludin을 포함한 밀착연접 단백들의 기능적 연구와 함께 미 세구조에 대한 검토도 의미 있는 연구라고 생각한다.

\section{요 약}

밀착연접(tight junction)은 사람의 표피에서 관찰되는 세포간 이음(intercellular junction) 중 하나로서, 표피 과립세포층의 세 포간격에 위치하여 인접한 세포들을 접합시키고 전해질과 수분의 이동을 조절하는 장벽기능을 비롯한 다양한 생물학적 기능을 수행 한다. 이러한 밀착연접의 대표적 단백성분인 occludin은 그 발현 도가 밀착연접의 표피-생물학적 기능성과 높은 상관관계가 있는 것으로도 알려져 있다. 본 연구에서는 신체 여러 부위의 정상피부 에서 occludin의 발현도 또는 발현정도의 상이성 여부를 알아보기 위하여 occludin에 대한 항체를 이용한 간접 면역형광검사를 시행 하여 그 결과를 비교 검토하고자 하였다. 신체 7개 부위별로 각 4 개 씩의 정상 피부조직을 채취하여 항 occludin 항체를 이용한 간접 면역형광검사를 시행한 결과, 양성반응을 보이는 최종 희석배수의 역수(reciprocal of end-point titer)로 표시한 부위별 occludin 항 원의 발현도는 두피에서 300 , 얼굴에서 600 , 목에서 300 , 팔에서 200 , 배에서 600 , 그리고 등과 다리에서는 모두 400 으로 관찰되어 신체 부위별 occludin의 발현도에는 통계학적으로 유의한 차이가 있음을 알 수 있었다 $(p=0.001)$.

본 연구에서 관찰된 신체 부위별 occludin의 발현도의 차이는 밀착연접의 부위별 발현의 차등을 시사하는 소견으로서, 표피 피부 장벽의 생물학적 기능의 가능한 부위별 차등성과도 관계가 있을 것 으로 사료된다.

\section{Acknowledgements: None}

Funding: None

Conflict of interest: None

\section{References}

1. Balda MS, Matter K. Transmembrane proteins of tight junctions. 
Semin Cell DevBiol. 2000,11:281-289.

2. Brandner JM, Kief S, Grund C, Rendl M, Houdek P, Kuhn C, et al. Organization and formation of the tight junction system in human epidermis and cultured keratinocytes. Eur J Cell Biol. 2002,81:253-263.

3. Brandner JM, McIntyre M, Kief S, Wladykowski E, Moll I. Expression and localization of tight junction-associated proteins in human hair follicles. Arch Dermatol Res. 2003,295: 211-221.

4. Conklin BS, Zhong DS, Zhao W, Lin PH, Chen C. Shear stress regulates occludin and VEGF expression in porcine arterial endothelial cells. J Surg Res. 2002,102:13-21.

5. Feldman GJ, Mullin JM, Ryan MP. Occludin: Structure, function and regulation. Adv Drug Deliv Rev. 2005,57:883-917.

6. Fluhr JW, Dickel H, Kuss O, Weyher I, Diepgen TL, Berardesca E. Impact of anatomical location on barrier recovery, surface $\mathrm{pH}$ and stratum corneum hydration after acute barrier disruption. Br J Dermatol. 2002,146:770-776.

7. Furuse M, Hata M, Furuse K, Yoshida Y, Haratake A, Sugitani Y, et al. Claudin-based tight junctions are crucial for the mammalian epidermal barrier. J Cell Biol. 2002,156:1099-1111.

8. Gonzalez-Mariscal L, Betanzos A, Nava P, Jaramillo BE. Tight junction proteins. Prog Biophys Mol Biol. 2003,81:1-44.

9. Gonzalez-Mariscal L, Namorado MC, Martin D, Luna J, Alarcon L, Islas S, et al. Tight junction proteins ZO-1, ZO-2, and occludin along isolated renal tubules. Kidney Int. 2000,57:23862402.

10. Green KJ, Gaudry CA. Are desmosomes more than tethers for intermediate filaments? Nat Rev Mol Cell Biol. 2000,1:208-216.

11. Gumbiner BM. Cell adhesion: The molecular basis of tissue architecture and morphogenesis. Cell. 1996,84:345-357.

12. Harhaj NS, Antonetti DA. Regulation of tight junctions and loss of barrier function in pathophysiology. Int J Biochem Cell Biol. 2004,36:1206-1237.

13. Hirase T, Furuse M, Itoh M, Nagafuchi A, Yonemura S, Tsukita S, et al, Occludin: A novel integral membrane protein localizing at tight junctions. J Cell Biol. 1993,123:1777-1788.

14. Hirase T, Staddon JM, Saitou M, Ando-akatsuka Y, Itoh M, Furuse M. Occludin as a possible determinant of tight junction permeability in endothelial cells. J Cell Sci. 1997,110:16031613.

15. Huzaira M, Rius F, Rajadhyaksha M, Anderson RR, Gonzalez S. Topographic variations in normal skin, as viewed by in vivo reflectance confocal microscopy. J Invest Dermatol. 2001,116: 846-852.

16. Lapierre LA. The molecular structure of the tight junction. $A d V$
Drug Deliv Rev. 2000,41:255-264.

17. Malminen M, Koivukangas V, Peltonen J, Karvonen SL, Oikarinen A, Peltonen S. Immunohistological distribution of the tight junction components ZO-1 and occludin in regenerating human epidermis. Br J Dermatol. 2003,149:255-260.

18. Matter K, Aijaz S, Tsapara A, Balda MS. Mammalian tight junctions in ther regulation of epithelial differentiation and proliferation. Curr Opin Cell Biol. 2005,17:453-458.

19. McGrath JA, Eady RA, Pope FM. Anatomy and organization of human skin, In: Burns T, Breathnach S, Cox N, Griffiths C. Rook's textbook of dermatology. 7th ed, 2004, p8-12. Blackwell publishing. Oxford.

20. Morita K, Miyachi Y. Tight junctions in the skin. J Dermatol Sci. 2003,31:81-89.

21. Ohnemus U, Kohrmeyer K, Houdek P, Rohde H, Wladykowski E, Vidal S, et al. Regulation of epidermal tight-junctions during infection with exfoliativ toxin-negative Staphylococcus strains. J Invest Dermatol In press. 2008,128(4):906-16.

22. Pummi K, Malminen M, Aho H, Karvonen SL, Peltonen J, Peltonen S. Epidermal tight junctions: ZO-1 and occludin are expressed in mature, developing, and affected skin and in vitro differentiating keratinocytes. J Invest Dermatol. 2001;117: 1050-1058.

23. Saitou M, Ando-Akatsuka Y, Itoh M, Furuse M, Inazawa J, Fujimoto K, et al Mammalian occludin in epithelial cells: its expression and subcellular distribution. Eur J Cell Biol. 1997, 73:222-231.

24. Schlüter H, Wepf R, Moll I, Franke WW. Sealing the live part of the skin: The integrated meshwork of desmosomes, tight junctions and curvilinear ridge structures in the cells of the uppermost granular layer of the human epidermis. Eur J Cell Biol. 2004,83:655-665.

25. Schneeberger EE, Lynch RD. The tight junction: a multifunctional complex. Am J physiol Cell Physiol. 2004,286:12131228.

26. Segre JA. Epidermal barrier formation and recovery in skin disorders. J Clin Invest. 2006,116:1150-1158.

27. Van Itallie CM, Anderson JM. Occludin confers adhesiveness when expressed in fibroblasts. J Cell Sci. 1997,110:1113-1121.

28. Wan H, Winton HL, Soeller C, Tovey ER, Gruenert DC, Thompson PJ, et al. Der p 1 facilitates transepithelial allergen delivery by disruption of tight junctions. J Clin Invest. 1999, 104:123-133.

29. Yoshida Y, Morita K, Mizoguchi A, Ide C, Miyachi Y. Altered expression of occludin and tight junction formation in psoriasis. Arch Dermatol. 2001,293:239-244. 